\title{
Optimization of processing parameters on the proximate properties of maize and soybean extrudates
}

\author{
Adefemiwa Ayobami Adekunle*1, Samuel Olusegun Awonorin ${ }^{2}$, Olajide Philip Sobukola ${ }^{2}$, Olawale Usman Dairo ${ }^{3}$, Oladipupo Olaosebikan \\ Ogunleye $e^{4}$
}

${ }^{1}$ Bioresources Development Centre, National Biotechnology Development Agency, Ogbomoso, Oyo State, Nigeria

${ }^{2}$ Department of Food Science and Technology, Federal University of Agriculture, Abeokuta, Ogun State, Nigeria

${ }^{3}$ Department of Agricultural Engineering, Federal University of Agriculture, Abeokuta, Ogun State, Nigeria

${ }^{4}$ Department of Chemical Engineering, Ladoke Akintola University of Technology, Ogbomoso, Oyo State, Nigeria

*Corresponding author: adekunleadefemiwa@gmail.com

\begin{abstract}
Maize (TZSR-W-1 NARZO-20) and soybean (TGX1448) flours were used for the development of extruded products. The flour formulations were maize (46-52\%), soybean (21-32\%), and moisture content (16-26\%). Central Composite Design (CCD) in Response Surface Methodology consisting five factors (maize to soybean-water weight ratio-X1, soybean to water weight ratio-X2, barrel temperature (120, 160 and 200oC) -X3, die diameter (6, 8 and 10mm) -X4 and screw speed (120, 160 and 200rpm) -X5 at three levels was used to determine the optimum process condition for the proximate properties of the extruded products. The process parameters significantly influenced the dependent variables at $p<0.05$. The coefficients of regression (R2) for the response equations ranged between 0.967 and 0.999 which is an indication that the variables were adequately fitted to the regression equation and could predict the proximate values of the extrudates. The optimum process condition at desirability index of 1 were XI (0.99), X2 (1.10), X3 (190oC), X4 (124rpm) and X5 (10mm).
\end{abstract}

\section{Keywords: maize, soybean, extrudates, barrel temperature, Screw speed, die diameter}

\section{Introduction}

Extrusion is an efficient continuous process in which several snack food and breakfast cereals are cooked and shaped. In other to produce food that are rich in fibre, factors, such as temperature, moisture, shearing and mixing are put into consideration. (Huang and Ma, 2016, Ajita and Jha, 2017). Extrusion has been known to be a highly versatile unit operation whose applications vary from the production and processing of plastics to the production of food and drugs. It has provided means of developing new products which have successfully revolutionize many conventional manufacturing processes (Sobowale et al., 2017).

Results from some previous researches showed that extrusion cooking has distinctive features that are likened to other heat processes due to its High Temperature, Short Time (HTST) operation. It reduces microbial contamination, inactivates enzymes and breaks covalent bonds in biopolymers and facilitates reactions otherwise limited by diffusing reactants and products (alam, 2010, Alam et al., 2016). Extrudatess are known to be safe microbiologically due to their low moisture content which enhances them to be stored for a long time without the need for refrigeration (ferr et al., 2013, Ferrari et al., 2014).

Navale et al. (2015) reported that extrusion of starchy food has become a very important procedure that has resulted in starch gelatinization and protein denaturation in the production of snacks and breakfast cereals. Since maize grits has been established to be widely used for expanded products, it is important that the nutritional components of this kind of food be improved. Alamu et al., (2016) reported that fortification of legumes and starchy food materials has been an effective approach in solving the problem of malnutrition mostly among children in the developing countries. Soybean is known to be rich in protein content. The higher percentage of protein in soybean makes it unique compared to other legumes (Rizzo and Baroni, 2018). A lower degree of maize replacement is needed to increase the nutritional value of expanded snacks or products, which in turn can help to keep consumer acceptability. Offiah, et al. (2018) reported that most of the available extruded products use maize grits as the main ingredient due to their low cost, abundance and high expansion capacity. However, it has been reported that maize has a limited nutrient profile with poor protein and dietary fibre contents. Patil et al., (2016) reported that fortification of starch-based snack food with legumes would improve their nutritional quality. Soybean is a major source of protein and edible oil which had entered the diets of lowincome populace in Nigerian in an attempt to increase nutrient intake. Awobusuyi et al. (2019) reported that a variety of snack food widely consumed by Nigerians are made of low-protein cereals with lysine and tryptophan as limiting amino acids that are essential for human nutrition. Incorporating this legume into maize grit as composite flour of maize and soybean in manner that the final products will satisfy basic food requirements and its appearance appealing to consumers becomes a subject of product development. One known analytical tool for product development is Response Surface Methodology (RSM).

RSM has been described as an effective tool for optimizing a process. It relays product properties by using regression equations that describe interrelations between input parameters and product properties (Borah et al., 2015). Some researchers have used RSM to optimize various ingredients and process conditions for the preparation of various extruded snack food for consumer acceptability (Borah et al., 2015, Offiah, et al. (2018). The objective of this research was to determine the best combination of extrusion process variables that will give optimum functional properties for the production of maize-soybean extrudates.

\section{Materials and methods}

\section{Preparation of samples}

Composite flour comprising of maize (TZSR-W-1 NARZO-20) and soybean (TGX1448) blend used in this study were purchased from old Sabo market in Ogbomoso, Oyo State, Nigeria. The method of Omohimi et. al. (2013) was used with a little modification in the preparation of the composite flour. The maize and soybean were sorted by handpicking 
stones, dirt, broken grains and foreign object. The maize and soybean samples were then dehulled, dry milled into flour using a milling machine and sieved to a particle size of $200 \mu \mathrm{m}$. The flours were then kept in a Ziploc polyethylene bag at $4 \mathrm{oC}$ until required.

\section{Extrusion Process}

Extrusion was done using a co-rotating intermeshing twin screw extruder. The composite flour (maize and soybean) was used for the extrusion cooking with various formulations of maize: $46-52 \%$, soybean: 21 $32 \%$ and moisture content: $16-26 \%$ to provide uniform water diffusion in the whole mass (Reddy et al., 2014). The parameters of the extrusion cooking process include extrusion barrel temperature $(120,160$ and $200 \mathrm{oC})$, screw speed $(120,160$ and $200 \mathrm{rpm})$ and die diameter $(6,8$ and $10 \mathrm{~mm}$ ). These are the parameters that guaranteed a stable course of the extrusion process and simultaneously enabled high quality products (Reddy et. al., 2014). Prior to extrusion cooking, 300g of each of the formulations was used for the extrusion at combinations of parameters as specified in the experimental design. Extrudates was collected, dried and packaged in Ziploc polyethylene bags and was kept for analysis.

\section{Proximate analysis}

The method of Association of Official Analytical Chemists (2014) was used to determine the proximate (moisture, protein, crude fibre, ash, crude lipids and carbohydrate) analysis of the extrudatess.

\section{Experimental design}

The study was based on the premise that proximate properties (moisture content, protein, crude fibre, ash, crude lipids and carbohydrate) were functionally linked to specific composition which was made to fit multiple regression equation that describes responses to quality composition. The lists of ingredients as shown in Table 1 are in descending order of assumed importance to quality variable. The snack composition have the form: A (Maize flour) $+\mathrm{B}$ (soybean flour) $+\mathrm{C}$ (water) $=100 \%$. According to Singh et al., (2003), this equation implies mathematical linear dependence of the variables on the condition that the amounts of ingredients are used directly as variables. To make the equation function in a multiple factor analysis, these ingredients could be in ratio form which can be varied independently. The ingredients ratios which were selected as xi variable are:

Table 1. Formula composition at the centre point of the design

\begin{tabular}{|l|l|l|}
\hline Ingredients & Total mixture basis (\%) & Weight $(\mathrm{g})$ \\
\hline Maize flour & 50 & 150 \\
Soybean flour & 24 & 72 \\
Water & 26 & 78 \\
& & 300 \\
\hline
\end{tabular}

From the above equations, the values of the independent ratios distinctively determined the amounts of the three ingredients. To get at least a satisfactory results, a centre point for the design was selected with the various ingredients. With the centre composition selected, the normal xi ratios were calculated by using the normal weight composition of the formulation given in Table 1. The increments of variation for each variable spaced around the centre point ratios, along with the equations relating the actual and coded ratios, are presented in Table 2.
Table 2. Experimental increments, values of coded levels and equations relating actual and coded ratios

\begin{tabular}{|c|c|c|c|c|}
\hline \multirow{2}{*}{$\mathrm{x}_{\mathrm{i}}$ Variables } & \multirow{2}{*}{ Increment } & \multicolumn{3}{|c|}{$\mathrm{x}_{\mathrm{i}}$ coded levels } \\
\cline { 3 - 5 } & & -1 & 0 & +1 \\
\hline $\mathrm{x}_{1}$ & 0.2 & 0.800 & 1.000 & 1.200 \\
$\mathrm{x}_{2}$ & 0.2 & 0.743 & 0.923 & 1.104 \\
$\mathrm{x}_{3}($ Temp) & 0.2 & 120 & 160 & 200 \\
$\mathrm{x}_{4}$ (Speed) & 0.25 & 120 & 160 & 200 \\
$\mathrm{x}_{5}$ (Die) & 0.25 & 6 & 8 & 10 \\
\hline
\end{tabular}

From the experimental design, the value of the coded xi ratios for each treatment were translated into working quantities of ingredients thereby leading to a systematic algebraic solutions for A, B and C in terms of actual xi ratios and a unit quantity of product. Equations derived for the general case follow:

$$
\begin{gathered}
A=\frac{100 x_{1}}{x_{1}+1} \\
B=\frac{100 x_{2}}{\left(x_{1}+1\right)\left(x_{2}+1\right)} \\
C=\frac{100}{\left(x_{1}+1\right)\left(x_{2}\right)+1}
\end{gathered}
$$

The actual weights for each ingredient in different treatments are given in Table 3. The Response Surface Methodology experimental design was based on a rotatable, central composite, response-surface model with five factors and three levels using design expert software 6.0.8 according to Cocharan and Cox (1957). The independent variable selected were: flour compositions(X1 and X2), barrel temperature (X3), screw speed (X4) and die diameter (X5). The three levels of the processing variables were coded as $-1,0,+1$ and the design is coded and at the actual levels is shown in Table 2. Table 3 shows the experimental design of the maize-soybean flour. The dependent variable were crude fibre, crude lipids, moisture content, ash content, protein, carbohydrate as product responses for the proximate properties.

\section{Analysis of Data}

Multiple regression analysis was used to fit the model, represented by an equation, to the experimental data. Maximization and minimization of the polynomial thus fitted was performed by numerical techniques, using mathematical optimizer procedure that deals with constraints. The constraints was set to get coded value of a variable between the lower and upper limits $(-1$ and +1$)$ for an optimum response (a minimum and a maximum level was provided for each parameter included). A weight was assigned to each goal to adjust the shape of its particular desirability function. The goals were; combined into an overall desirability function. The program seeks to maximize this function.

The goal seeking begins at a random starting point and proceeds up the steepest slope to a maximum. There may be two or more maximums because of curvature in the response surfaces and their combination into the desirability function. By starting from several points in the design space changes improve for finding the 'best' local maximum. The mapping of the fitted responses was achieved using design expert software 6.0.8. The response surfaces and contour plots for these models was plotted as a function of two variables, while keeping the other three variables at the optimum level. The overlapping of the topographs was done to take into account the two responses for their optimum values corresponding to two variables at a time. 
Table 3. Central composite design arrangement

\begin{tabular}{|l|l|l|l|l|l|}
\hline \multicolumn{5}{|l|}{ Treatment level Composition } \\
\hline Expt. No & $\mathrm{X}_{1}$ & $\mathrm{X}_{2}$ & $\mathrm{X}_{3}$ & $\mathrm{X}_{4}$ & $\mathrm{X}_{5}$ \\
\hline 1 & 1.20 & 0.74 & 120 & 200 & 10.00 \\
2 & 0.80 & 0.92 & 160 & 160 & 8.00 \\
3 & 0.80 & 1.10 & 120 & 200 & 10.00 \\
4 & 0.80 & 0.74 & 200 & 200 & 10.00 \\
5 & 1.00 & 0.92 & 160 & 160 & 6.00 \\
6 & 0.80 & 0.74 & 120 & 120 & 6.00 \\
7 & 1.00 & 0.92 & 120 & 160 & 8.00 \\
8 & 1.00 & 0.92 & 160 & 160 & 8.00 \\
9 & 0.80 & 1.10 & 200 & 120 & 10.00 \\
10 & 1.00 & 0.92 & 200 & 160 & 8.00 \\
11 & 1.00 & 0.92 & 160 & 120 & 8.00 \\
12 & 1.00 & 1.10 & 160 & 160 & 8.00 \\
13 & 1.00 & 0.92 & 160 & 200 & 8.00 \\
14 & 1.20 & 1.10 & 200 & 120 & 6.00 \\
15 & 1.20 & 0.74 & 200 & 200 & 6.00 \\
16 & 1.00 & 0.92 & 160 & 160 & 10.00 \\
17 & 0.80 & 1.10 & 200 & 200 & 6.00 \\
18 & 1.20 & 1.10 & 120 & 120 & 10.00 \\
19 & 1.20 & 0.92 & 160 & 160 & 8.00 \\
20 & 1.00 & 0.74 & 160 & 160 & 8.00 \\
21 & 1.20 & 1.10 & 120 & 200 & 6.00 \\
22 & 1.20 & 0.74 & 200 & 120 & 10.00 \\
\hline
\end{tabular}

\section{Results and discussion}

\section{Diagnostic checking of the fitted models}

The main effects, linear and quadratic, and their interaction for each model were calculated. Table 4 shows the regression and correlation coefficients for each model. The coefficients of determination (R2) for the responses (crude fibre, crude lipids, moisture content, ash, total protein and carbohydrate) were $0.983,0.999,0.991,0.978,0.996$ and 0.967 respectively. The values are quite high for response surfaces and the indications show that the fitted quadratic models accounted for more than $95 \%$ of the variance in the experimental data, which were found to be highly significant. The regression coefficients significant at $95 \%$ and $99 \%$ based on t-statistics were selected for developing the following models:

Crude Fibre, $\mathrm{M} 1=1.83522+4.935 \mathrm{X} 1-8.95011 \mathrm{X} 2+0.031955 \mathrm{X} 3+$ $0.031223 \mathrm{X} 4-0.78278 \mathrm{X} 5-0.63889 \mathrm{X} 12-0.28255 \mathrm{X} 22-9.8 \mathrm{E}-06 \mathrm{X} 32$ $-1.2 \mathrm{E}-05 \mathrm{X} 42-0.00528 \mathrm{X} 52+2.936602 \mathrm{X} 1 \mathrm{X} 2-0.02932 \mathrm{X} 1 \mathrm{X} 3-$ $0.02331 \mathrm{X} 1 \mathrm{X} 4+0.223341 \mathrm{X} 1 \mathrm{X} 5+0.017657 \mathrm{X} 2 \mathrm{X} 3+0.011958 \mathrm{X} 2 \mathrm{X} 4+$ $0.251832 \mathrm{X} 2 \mathrm{X} 5-0.00017 \mathrm{X} 3 \mathrm{X} 4+0.001379 \mathrm{X} 3 \mathrm{X} 5+0.001244 \mathrm{X} 4 \mathrm{X} 5$

Crude Lipids, $\mathrm{M} 2=2.066604+8.298747 \mathrm{X} 1+1.584051 \mathrm{X} 2+0.02777 \mathrm{X} 3$ $-0.03483 \mathrm{X} 4-0.89208 \mathrm{X} 5+1.071296 \mathrm{X} 22+9.48 \mathrm{E}-05 \mathrm{X} 32-2.3 \mathrm{E}-05 \mathrm{X} 42$ -0.05066 X52 - 4.08636X1X2 - 0.0487X1X3 - 0.01373X1X4 + $0.611831 \mathrm{X} 1 \mathrm{X} 5-0.0198 \mathrm{X} 2 \mathrm{X} 3+0.02489 \mathrm{X} 2 \mathrm{X} 4-5.2 \mathrm{E}-05 \mathrm{X} 3 \mathrm{X} 4+$ $0.002435 \mathrm{X} 3 \mathrm{X} 5+0.004278 \mathrm{X} 4 \mathrm{X} 5$

Moisture Content, $\mathrm{M} 3=8.450564-13.9437 \mathrm{X} 1+17.77164 \mathrm{X} 2-$ $0.0625 \mathrm{X} 3-0.06931 \mathrm{X} 4+1.944104 \mathrm{X} 5+2.285078 \mathrm{X} 12+0.28708 \mathrm{X} 22$ $+4.55 \mathrm{E}-05 \mathrm{X} 32+2.19 \mathrm{E}-05 \mathrm{X} 42+0.004013 \mathrm{X} 52-4.72908 \mathrm{X} 1 \mathrm{X} 2+$ $0.062582 \mathrm{X} 1 \mathrm{X} 3+0.052032 \mathrm{X} 1 \mathrm{X} 4-0.50055 \mathrm{X} 1 \mathrm{X} 5-0.03672 \mathrm{X} 2 \mathrm{X} 3-$ $0.02114 \times 2 \times 4$

Ash Content, M4 $=9.702857-2.02322 \mathrm{X} 1+2.150759 \mathrm{X} 2-0.0143 \mathrm{X} 3-$ $0.0176 \mathrm{X} 4+0.625644 \mathrm{X} 5+0.387782 \mathrm{X} 12+1.137538 \mathrm{X} 22+9.01 \mathrm{E}-06 \mathrm{X} 32$ -0.0012 X52 - 1.49307X1X2 + 0.014953 X1X3 + 0.012875X1X4 $0.19906 \mathrm{X} 1 \mathrm{X} 5-0.0093 \mathrm{X} 2 \mathrm{X} 3-0.00398 \mathrm{X} 2 \mathrm{X} 4-0.11143 \mathrm{X} 2 \mathrm{X} 5+9.45 \mathrm{E}-$ 05 X3X4 - 0.00122X3X5 - 0.00075X4X5

Total Protein, M5 = 45.9601 + 32.4904X1 - 84.1062X2 + 0.018391X3 + $0.289857 \mathrm{X} 4-5.1851 \mathrm{X} 5-10.1956 \mathrm{X} 12+2.384129 \mathrm{X} 22+4.17 \mathrm{E}-05 \mathrm{X} 32$ $-0.00019 X 42-0.04083 X 52+25.55456 \mathrm{X} 1 \mathrm{X} 2-0.16309 \mathrm{X} 1 \mathrm{X} 3-$ $0.16719 \mathrm{X} 1 \mathrm{X} 4+1.828174 \mathrm{X} 1 \mathrm{X} 5+0.191173 \mathrm{X} 2 \mathrm{X} 3+0.094913 \mathrm{X} 2 \mathrm{X} 4$

Carbohydrate, M6 = $32.17164-30.2283 \mathrm{X} 1+71.41453 \mathrm{X} 2+$ $2.01 \mathrm{E}-05 \mathrm{X} 3-0.19841 \mathrm{X} 4+4.271161 \mathrm{X} 5+8.437035 \mathrm{X} 12-4.67672 \mathrm{X} 22$

$-0.00018 X 32+0.000205 X 42+0.093395 X 52-18.1283 X 1 X 2+$ $0.163084 X 1 X 3+0.138834 X 1 X 4-1.95883 X 1 X 5-0.14293 X 2 X 3$ $-0.10638 X 2 X 4-0.89662 X 2 X 5+0.000934 X 3 X 4-0.01475 X 3 X 5-$ $0.00612 \mathrm{X} 4 \mathrm{X} 5$

\section{Influence of process parameters on the crude fiber of maize-soybean extrudates}

Several researchers have reported that high intake of crude fibre prevents diet related diseases such as cardiovascular disease, cancer of the colon and diabetes (Schulze et al., 2004; Rimm et al., 1996). It has also been established that crude fibre plays a physiological roles in the maintenance of the peristaltic movement of the intestinal tract thereby preventing constipation (Odour et al., 2008). The crude fibre for the maize-soybean extrudates ranged from 0.527 to $2.345 \%$. The linear, quadratic and interaction coefficients of the model as well as the t-test value are shown in Table 4. The model equation coefficients of maize ratio (X1), barrel temperature (X3) and screw speed (X4) are found to be positive while the soybean ratio (X2) and die diameter (X5) are negative. This implies that as maize ratio, barrel temperature and screw speed increase, the crude fibre increases whereas increase in soybean ratio and die diameter may leads to reduction in the crude fibre of the products. The quadratic effects shows a negative sign on the process parameters which is an indication that the maximum crude fibre will occur in the range of the maize ratio, soybean ration, barrel temperature, screw speed and die diameter considered in this study. It was observed that an increase in temperature and die diameter leads to increase in the crude fibre. Reports on the influence of extrusion variables on proximate composition of some nutrient and antinutrient contents of dakuwa extrudates produced from blends of sorghum stated that barrel temperature affect the crude fibre content of the extrudates, as the barrel temperature increased (Yusuf et al., 2018). Omohimi et al., (2013) supported this trend. The changes (increase or decrease) in the crude fibre has been reported to be insignificant when extrusion is carried out at mild condition while a major changes is observed at a severe condition (Singh et al., 2007). This changes could be attributed to alterations in the structure of the fibre which tends to shift form from insoluble state to soluble state (Omohimi et al., 2013). The crude fibre content of the

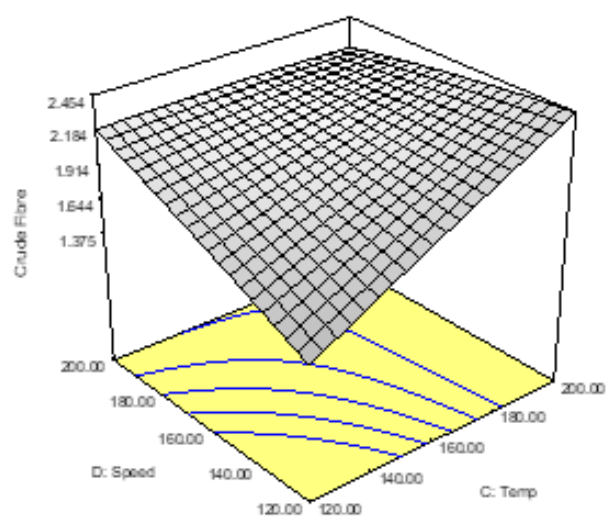

Figure 1. Response surface plot for crude fibre as a function of barrel temperature and screw speed 
Table 4. Estimated coefficients of the fitted quadratic equation for different responses based on $t$-statistic

\begin{tabular}{|c|c|c|c|c|c|c|c|c|c|c|c|c|}
\hline \multicolumn{13}{|c|}{ Estimated Coefficients } \\
\hline \multirow{2}{*}{ Factors } & \multicolumn{2}{|c|}{ Crude Fibre } & \multicolumn{2}{|c|}{ Crude Lipids } & \multicolumn{2}{|c|}{ Moisture Content } & \multicolumn{2}{|c|}{ Ash Content } & \multicolumn{2}{|c|}{ Total Protein } & \multicolumn{2}{|c|}{ Carbohydrate } \\
\hline & Coefficients & $t$-Value & Coefficients & $\mathrm{t}$-Value & Coefficients & $\mathrm{t}$-Value & Coefficients & $t$-Value & Coefficients & $\mathrm{t}$-Value & Coefficients & $t$-Value \\
\hline Xo & $1.83522 * *$ & 3.028 & $2.066604 * *$ & 4.493 & $8.450564 * *$ & 3.171 & $9.702857^{* * *}$ & 4.493 & $45.9601 * *$ & 3.001 & $32.17164 * *$ & 3.118 \\
\hline $\mathrm{X} 1$ & $4.935^{*}$ & 2.457 & $8.298747 * *$ & 3.743 & $-13.9437^{* * *}$ & -2.643 & $-2.02322^{* *}$ & -4.493 & $32.4904 * *$ & 2.518 & $-30.2283^{* *}$ & -2.643 \\
\hline $\mathrm{x} 2$ & $-8.95011^{*}$ & \begin{tabular}{|l|}
-2.315 \\
\end{tabular} & $1.584051 * *$ & 2.773 & $17.77164^{*}$ & 2.374 & $2.150759 * *$ & 4.493 & $-84.1062^{*}$ & -2.425 & $71.41453^{* *}$ & 2.571 \\
\hline $\mathrm{X} 3$ & 0.031955 & 1.664 & $0.02777 * *$ & 3.487 & $-0.0625^{*}$ & -2.392 & $-0.0143 * *$ & -3.355 & $0.018391 *$ & 2.294 & $2.01 \mathrm{E}-05^{*}$ & 2.102 \\
\hline $\mathrm{X} 4$ & $0.031223^{* *}$ & 2.527 & $-0.03483^{* *}$ & 4.493 & $-0.06931^{* *}$ & -2.582 & $-0.0176 * *$ & -4.033 & $0.289857^{*}$ & 1.741 & $-0.19841^{*}$ & -2.437 \\
\hline $\mathrm{X} 5$ & $-0.78278^{*}$ & \begin{tabular}{|l|l|}
-1.893 \\
\end{tabular} & $-0.89208^{*}$ & 2.189 & 1.944104* & 2.132 & $0.625644 * *$ & 4.033 & $-5.1851^{* *}$ & -2.687 & $4.271161^{* *}$ & 2.797 \\
\hline $\mathrm{X} 12$ & $-0.63889^{*}$ & \begin{tabular}{|l|l|}
-2.154 \\
\end{tabular} & - & - & $2.285078^{* *}$ & 2.566 & $0.387782^{* *}$ & 3.678 & $-10.1956^{*}$ & -2.421 & $8.437035^{*}$ & 2.500 \\
\hline $\mathrm{X} 22$ & -0.28255 & \begin{tabular}{|l|l|}
-1.624 \\
\end{tabular} & $1.0716^{*}$ & 2.282 & 0.28708 & 1.404 & $1.137538^{* *}$ & 4.493 & 2.384129 & 1.581 & $-4.67672^{*}$ & -2.121 \\
\hline $\mathrm{X} 32$ & $-9.8 \mathrm{E}-06^{*}$ & \begin{tabular}{|l|}
-1.909 \\
\end{tabular} & $9.48 \mathrm{E}-05 * *$ & 4.203 & 4.55E-05* & 2.461 & $9.01 \mathrm{E}-06 * *$ & 3.621 & $4.17 \mathrm{E}-05$ & 1.495 & $-0.00018^{*}$ & -2.433 \\
\hline $\mathrm{X} 42$ & $-1.2 \mathrm{E}-05^{*}$ & \begin{tabular}{|l|}
-2.018 \\
\end{tabular} & $-2.3 \mathrm{E}-05^{*}$ & 2.350 & $2.19 \mathrm{E}-05^{*}$ & 2.110 & $-0.00128 * *$ & -2.757 & $-0.00019^{*}$ & -2.288 & $0.000205^{*}$ & 2.486 \\
\hline $\mathrm{X} 52$ & $-0.00528^{*}$ & -2.060 & $-0.05066^{* *}$ & 4.493 & 0.004013 & 1.709 & $-1.49307^{* * *}$ & -4.493 & $-0.04083^{*}$ & -1.976 & $0.093395 * *$ & 2.546 \\
\hline $\mathrm{X} 1 \mathrm{X} 2$ & $2.936602 * *$ & 2.674 & $-4.08636^{* *}$ & 3.743 & $-4.72908 * *$ & -2.707 & $0.014953^{* *}$ & 4.493 & $25.55456^{* *}$ & 2.655 & $-18.1283^{* * *}$ & -2.662 \\
\hline $\mathrm{X} 1 \mathrm{X} 3$ & $-0.02932 * *$ & \begin{tabular}{|l|}
$\mid-3.028$ \\
\end{tabular} & $-0.0487^{* *}$ & 4.493 & $0.062582^{* *}$ & 3.190 & $0.012875^{* *}$ & 4.493 & $-0.16309^{* *}$ & -2.814 & $0.163084^{* *}$ & 2.964 \\
\hline $\mathrm{X} 1 \mathrm{X} 4$ & $-0.02331 * *$ & \begin{tabular}{|l|}
-2.930 \\
\end{tabular} & $-0.01373 * *$ & 3.572 & $0.052032 * *$ & 3.102 & $-0.19906 * *$ & -4.493 & $-0.16719 * *$ & -2.823 & $0.138834 * *$ & 2.898 \\
\hline $\mathrm{X} 1 \mathrm{X} 5$ & $0.223341 * *$ & 2.598 & $0.611831 * *$ & 4.493 & $-0.50055^{* *}$ & -2.781 & $-0.0093 * *$ & -4.493 & $1.828174 * *$ & 2.546 & $-1.95883^{* * *}$ & -2.743 \\
\hline $\mathrm{X} 2 \mathrm{X} 3$ & $0.017657^{* *}$ & 2.757 & $-0.0198^{* *}$ & 3.678 & $-0.03672 * *$ & -2.909 & $-0.00398 * *$ & -3.913 & $0.191173 * *$ & 2.831 & $-0.14293 * *$ & -2.868 \\
\hline $\mathrm{X} 2 \mathrm{X} 4$ & $0.011958 * *$ & 2.582 & $0.02489 * *$ & 3.913 & $-0.02114 * *$ & -2.662 & $-0.11143^{* *}$ & -4.203 & $0.094913^{* *}$ & 2.518 & $-0.10638^{* *}$ & -2.735 \\
\hline $\mathrm{X} 2 \mathrm{X} 5$ & $0.251832 * *$ & 2.609 & - & - & $-0.58572 * *$ & -2.805 & 9.45E- $05 * *$ & 4.493 & $1.361551^{*}$ & 2.364 & $-0.89662^{*}$ & -2.334 \\
\hline $\mathrm{X} 3 \mathrm{X} 4$ & $-0.00017 * *$ & 3.086 & $-5.2 \mathrm{E}-05 * *$ & 3.190 & $0.000321 * *$ & 3.190 & $-0.00122 * *$ & -4.493 & $-0.00113^{* *}$ & -2.953 & $0.000934 * *$ & 3.028 \\
\hline $\mathrm{X} 3 \mathrm{X} 5$ & $0.001379 * *$ & 2.694 & $0.002435^{* *}$ & 4.033 & $-0.0038^{* * *}$ & -2.964 & $-0.00075^{* *}$ & $\mid-4.493$ & $0.01596^{* *}$ & 2.797 & $-0.01475^{* *}$ & -2.919 \\
\hline $\mathrm{X} 4 \mathrm{X} 5$ & $0.001244 * *$ & 2.649 & $2.066604 * *$ & 4.493 & $-0.00237^{* *}$ & -2.757 & $9.702857^{* *}$ & 4.493 & $0.003744 * *$ & 3.086 & $-0.00612 * *$ & -2.527 \\
\hline R2 & 0.983 & \begin{tabular}{|l|l|}
0.999 \\
\end{tabular} & 0.991 & 0.978 & 0.996 & 0.967 & & & & & & \\
\hline
\end{tabular}

$* \mathrm{P}<0.05$ (1.721), ${ }^{* *} \mathrm{P}<0.01$ (2.518) for d.f. $=21$

The $\mathrm{t}$-values in bold indicate the significance at different $\mathrm{P}$ levels.

maize-soybean composition shows a significant difference at $\mathrm{p}<0.05$ while the regression model developed to predict the content of the crude fibre explained $98.3 \%$ of the variations.

\section{Influence of process parameters on the crude lipids of maize-soybean extrudates}

Crude lipids are one of the major constituents of foods, and are important in our diet for a number of reasons. The crude lipid content found in the maize-soybean extrudates ranged between 0.602 and $2.716 \%$. The coefficients of the model and t- values are given in Table 4 . The $\mathrm{R} 2$ value for the crude lipid $(99.9 \%)$ was high showing that a high proportion of variability was explained by the model. It is obvious from crude lipids model equation that coefficients of moisture ratio (X1), soybean ratio (X2) and barrel temperature (X3) are positive, while screw speed (X4) and die diameter (X5) are negative. Increase in screw speed and die diameter may likely reduce the crude lipids in the maize-soybean extrudates, whereas increase in the feed ratio (maize and soybean) and barrel temperature may increase the crude lipids. The reason for increase in crude lipids as barrel temperature increases could be as a result of gelatinization of the starch granules of the feed composition in the course of extrusion cooking which in turns exposed the internal matrix to thermal energy thus, melting the fat. This melting of the fat consequently increased its level in the final product (Omohimi et al., 2013). Increase in screw speed was found to decrease the crude lipids. This may be attributed to short residence time of the feed composition in the extruder which consequently reduced the exposure rate to thermal energy which is responsible for the melting of the fat.

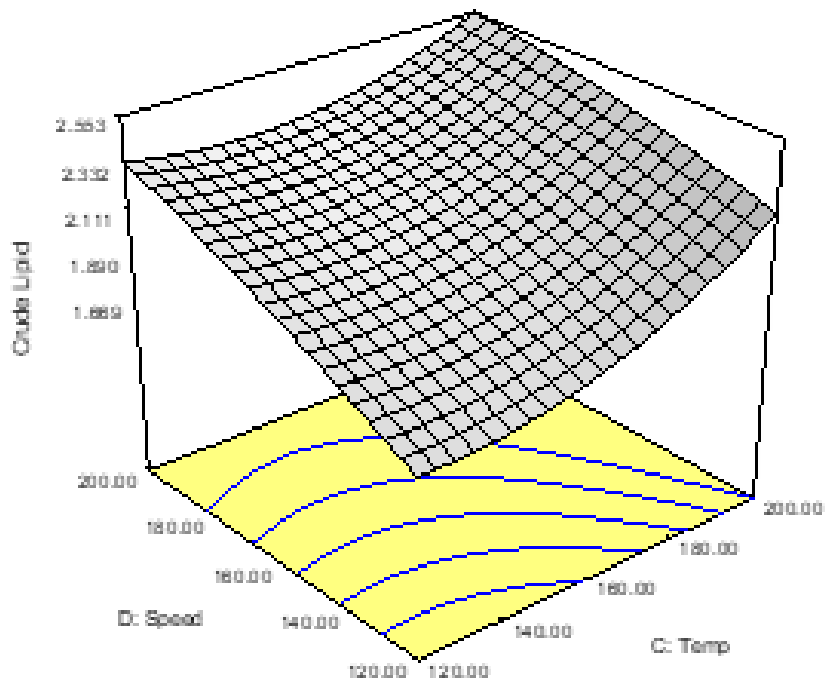

Figure 2. Response surface plot for crude lipids as a function of barrel temperature and screw speed 


\section{Influence of process parameters on the moisture content of maize-soybean extrudates}

Values between 6.607 and $10.434 \%$ were observed for the moisture content of maize-soybean extrudates sample. It has been established that the amount of moisture content in a food material determines the shelf life of the product (Ogunmodimu et al., 2015). The lower the moisture content in a food, the lower the microbial activities and the higher the storage period of the food products (Olitino et al., 2007; Ashworth et al., 1992). The values reported falls within the range that could prevent microbial activities which enhances spoilage and ensure shelf stability of the extrudates. The linear, quadratic and interaction coefficients are shown in Table 4 revealed that maize ratio(X1), barrel temperature (X3) and screw speed (X4) are negative. This implies that there may be reduction in the moisture content of the extrudates as the maize ratio, barrel temperature and screw speed increase. Soybean ratio (X2) and die diameter (X5) on the other hand, were found to have positive coefficients, an indication that moisture content increase as soybean and die diameter increases. The regression model predicts that moisture content could explain $99.1 \%$ of the variation. Omohimi et al., (2013) findings on extrusion of mucuna flour reported that an increase in temperature and speed reduced the moisture content of the extrudates. Moisture content was also reported to decrease from 6.09 to $5.84 \%$ as barrel temperature increases from $90^{\circ} \mathrm{C}$ to $110^{\circ} \mathrm{C}$ (Yusuf et al., 2018). The trend could be as a result of the structural changes in the food protein which is induced by temperature and screw speed, therefore leading to shrinkage that causes pressure driven flow of water out of the extrudates resulting in reduction in water holding capacity.

\section{Influence of process parameters on ash content of maize- soybean extrudates}

The ash content of any food material is an indication of the amount of the inorganic elements present as minerals in the food substance. The least ash content of $6.436 \%$ was recorded, representing $200^{\circ} \mathrm{C}$ barrel temperature and $120 \mathrm{rpm}$ screw speed while the highest ash content of $10.600 \%$ was recorded at $200^{\circ} \mathrm{C}$ barrel temperature and $200 \mathrm{rpm}$ screw speed respectively. The regression equation of the ash content showed that the coefficients of moisture ratio (X1), barrel temperature (X3) and screw speed (X4) are negative. This indicates that increase in barrel temperature and screw speed may reduce the ash content of the

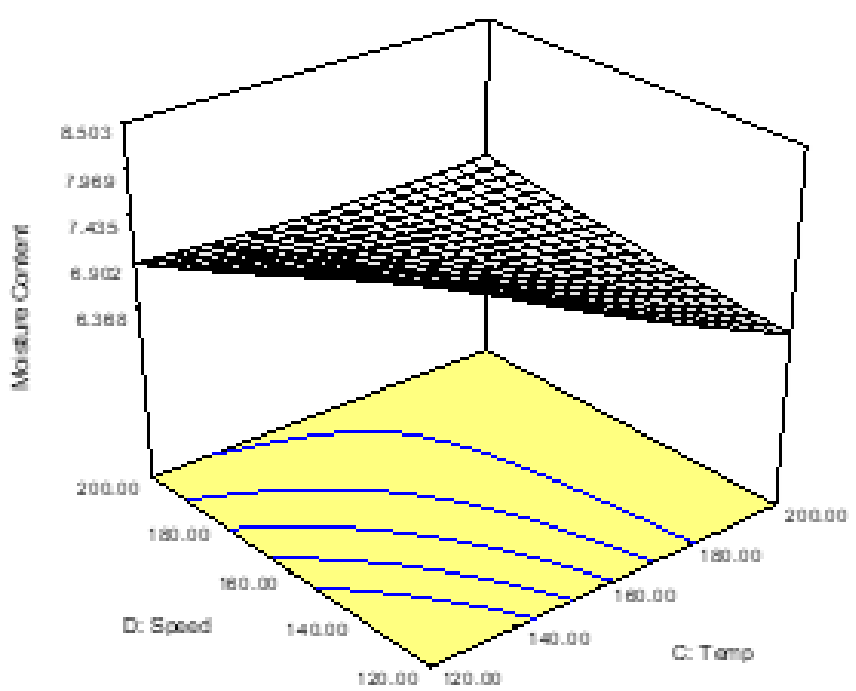

Figure 3. Response surface plot for moisture content as a function of barrel temperature and screw speed extrudatess. Study on the fortification of cereals with legumes (groundnut and cowpea) showed a similar trend (Asare et al., 2010). Increase in soybean (X2) and die diameter (X5) was found from the regression equation to increase the ash content of the extrudatess. The $\mathrm{R} 2$ value $(97.8 \%)$ observed for the ash content of the maize-soybean extrudates showed that the regression model was suitable for describing the effect of the independent variables on the ash content of the extrudates. The barrel temperature and screw speed showed significant effect on the ash content at $\mathrm{p}<0.05$. Singh et al., (2000) reported that higher temperature favoured ash content of any food material while increase in speed might be attributed to addition of these minerals through process water during extrusion and through the barrel temperature.

\section{Influence of process parameters on protein content of maize-soybean extrudates}

Proteins are group of highly complex organic compounds that are made up of a sequence of amino acids. During extrusion cooking, protein structures are disrupted and altered under high shear, pressure and temperature. The total protein value of the maize-soybean extrudatess ranged from 15.659 to $30.957 \%$. The minimum total protein content value represent the process parameter $200^{\circ} \mathrm{C}$ barrel temperature, 120 rpm screw speed while the maximum was recorded at $200^{\circ} \mathrm{C}$ barrel temperature and $200 \mathrm{rpm}$ screw speed respectively. The regression model equation shows that the soybean ratio (X2), and die diameter (X5) are negative however, the maize ratio (X1), barrel temperature (X3) and screw speed (X4) are positive. The inference of this equation is that there may be increase in the total protein as maize ratio, barrel temperature and screw speed increase while the negative effects may be an indication of reduction on the total protein as soybean ratio and die diameter increases. The regression coefficients are shown in Table 4. All the variables observed have significant effect at $p<0.05$ on the protein content. It was observed that as the barrel temperature increased, there was a remarkable decrease in the protein content of the sample while an increase was observed when the speed of rotation increased. This trend is similar to the findings Omohimi et al., 2013 on extrusion of meat analogue. Leszek (2011) observed in his research that the protein content of the extrudates of full fat blend of african breadfruit-soybean-corn snack decreased significantly $(p<0.05)$ on exposure to temperature. This may be due to the fact that high temperature, high shear and high pressure exposed the chemical constituent of the feed material during extrusion cooking thereby improving or damaging the nutritional quality of the

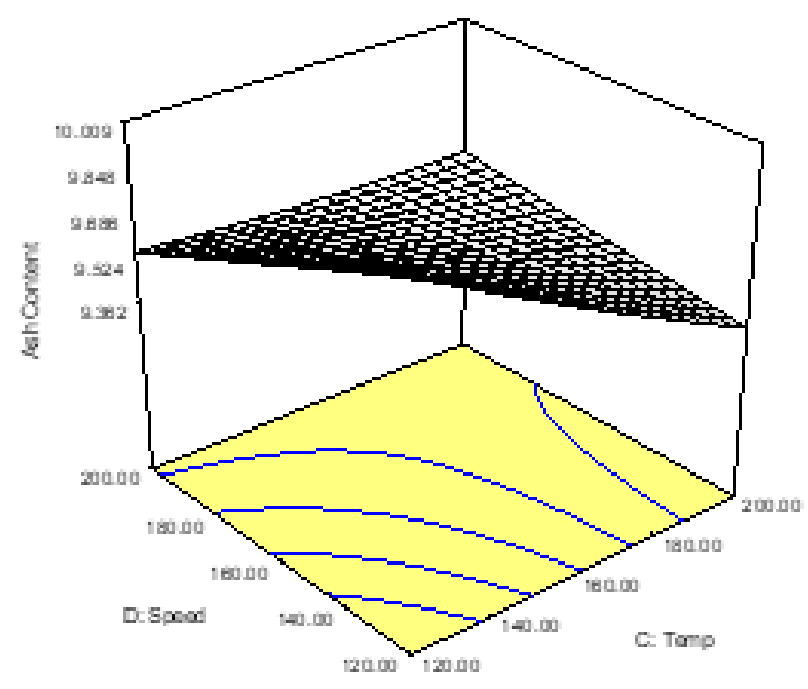

Figure 4. Response surface plot for ash content as a function of barrel temperature and screw speed 
protein in the extrudates by various mechanisms (Leszek, 2011). Several researchers reported that the decrease in the protein content could be as a result of the denaturation of the protein due to thermal energy which the food materials was subjected to during extrusion cooking (Colonna and Mercier, 1983; Pérez et al., 2008; Omohimi et al., 2013). The increase in the speed of rotation of the screw resulted in an increase in the protein content of the MS extrudates. At a low screw speed, the thermal energy absorbed by the feed resulted in decrease of protein. Reports from Sobukola et al., (2012), Bhattacharya and Hanna (1985) showed that protein digestibility increased as screw speed increased during the extrusion of corn-gluten and yam starch-based pasta. The increase might be due to the facts that shear forces in the extruder denatures proteins which in turn facilitate enzyme hydrolysis. The $\mathrm{R} 2$ value from the model equation was found to be $99.6 \%$ which shows that the regression model was very suitable for describing the protein content of the sample under the extrusion cooking variables.

\section{Influence of process parameters on carbohydrates content of maize-soybean extrudates}

Carbohydrates are the most important source of energy for the body and they range from simple sugars to complex molecules. For the maizesoybean extrudates the carbohydrate ranged from 48.179 to $62.178 \%$. The regression equation inferred that the maize ratio (X1) and the screw speed (X4) are negative. This is an indication that the carbohydrate content may reduce as maize ratio and screw speed increases. Soybean ratio (X2), barrel temperature $(\mathrm{X} 3)$ and die diameter $(\mathrm{X} 5)$ revealed a positive sign which indicates an increase as soybean, barrel temperature and die diameter increases. The R2 value from the model equation was found to be $99.6 \%$. This shows that the regression model was very suitable for describing the protein content.

Report from Samaila and Nwabueze (2013) confirmed this trend. The increasing trend in carbohydrate as barrel temperature and screw speed increases may be attributed to intense mechanical shearing which can bring mechanical breakage of bonds that are capable of holding some carbohydrate contents during the process of extrusion cooking. Wang and Klopfenstein (1993) reported that the conditions that increase temperature, share and pressure tend to increase the rate of gelatinization which inturns improve the digestibility of the product.

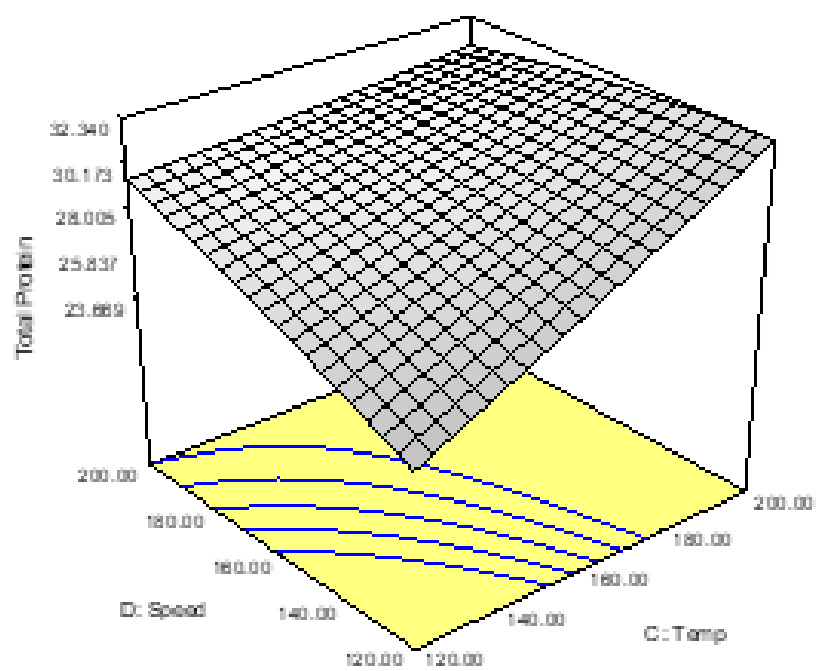

Figure 5. Response surface plot for total protein content as a function of barrel temperature and screw speed

\section{Analysis of variance}

Analysis of variance was calculated from the model selected to assess how well the model represented the data. Table 5 shows the analysis of variance for the responses. The F-values for crude fibre, crude lipids, moisture content, ash content, total protein and carbohydrate $(0.0023$, $0.0032,<0.0001,<0.0001,0.0034$ and 0.0026 respectively) were significant at the $99 \%$ level. It can be established on this note that the models selected adequately fit the data for crude fibre, crude lipids, moisture content, ash content, total protein and carbohydrate.

\section{Conditions for optimum responses}

The models (M1, M2, M3, M4, M5 and M6) were appropriate for demonstrating the path in which variables changes in order to maximize total protein, minimize moisture content and make other responses in range. The multiple regression equations were solved for the maximum total protein $(30.957 \mathrm{~g})$ and minimum moisture content $(6.607 \%)$. The optimum extrusion conditions were (maize to soybean-water ratio, $\mathrm{X} 1=$ 0.99), (soybean to water, $X 2=1.10$ ), (temperature, $X 3=190 \circ C$ ), (screw speed, $X 4=124 \mathrm{rpm}$ ) and (die diameter, $\mathrm{X} 5=10 \mathrm{~mm}$ ) while the optimum values were crude fibre $=2.327$, crude lipids $=2.114$, moisture content $=6.609$, ash content $=9.436$, total protein $=31.328$ and carbohydrate $=$ 48.179 , at a desirability constraint of 1 .

\section{Conclusions}

Processing variables such as (barrel temperature, screw speed and die diameter) significantly affected the proximate properties of the extrudates. The proximate properties of the extrudates were mostly affected by barrel temperature. The optimization results based on desirability concept of the extrudates indicated that the barrel temperature (190oC), screw speed (124rpm) and die diameter $(10 \mathrm{~mm})$ with feed formulation ratio of maize to soybean-water ratio $(0.99)$ and soybean to water ratio (1.10) would produce maize-soybean extrudates of preferable proximate composition.

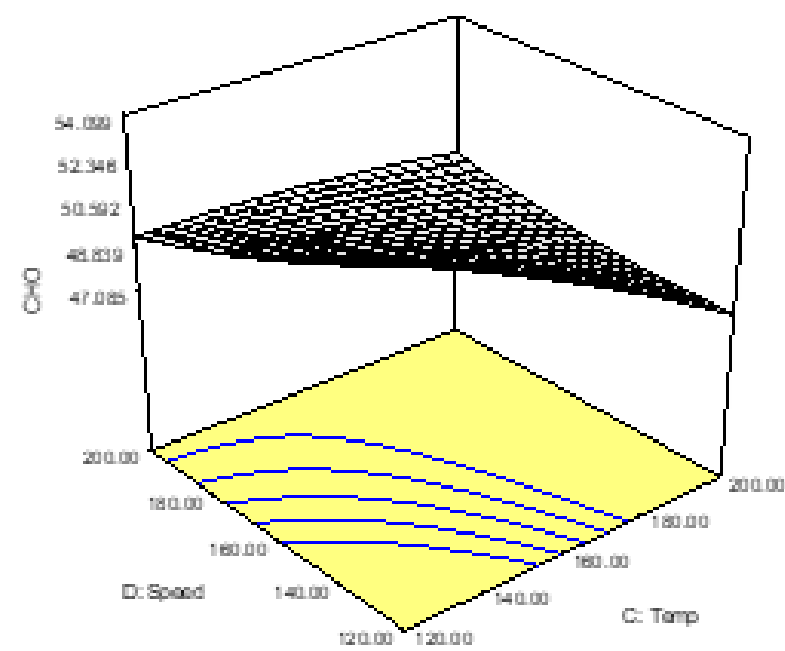

Figure 6. Response surface plot for carbohydrate content as a function of barrel temperature and screw speed 
Table 5. Analysis of Variance for the responses models

\begin{tabular}{|c|c|c|c|c|c|}
\hline Responses & Sources of Variation & $\begin{array}{l}\text { Degree of } \\
\text { Freedom }\end{array}$ & Sum of Square & Mean Square & F-Value \\
\hline Moisture Content & $\begin{array}{l}\text { Regression } \\
\text { Residual } \\
\text { Total }\end{array}$ & $\begin{array}{l}20 \\
1 \\
21\end{array}$ & $\begin{array}{l}9.94 \\
4.062 \mathrm{E}-006 \\
9.94\end{array}$ & $\begin{array}{l}0.50 \\
4.062 \mathrm{E}-006\end{array}$ & $0.0023 * *$ \\
\hline Crude Fibre & $\begin{array}{l}\text { Regression } \\
\text { Residual } \\
\text { Total }\end{array}$ & $\begin{array}{l}20 \\
1 \\
21\end{array}$ & $\begin{array}{l}2.24 \\
1.815 \mathrm{E}-006 \\
2.24\end{array}$ & $\begin{array}{l}0.11 \\
1.815 \mathrm{E}-006\end{array}$ & $0.0032 * *$ \\
\hline Crude Lipids & $\begin{array}{l}\text { Regression } \\
\text { Residual } \\
\text { Total }\end{array}$ & $\begin{array}{l}18 \\
3 \\
21\end{array}$ & $\begin{array}{l}3.83 \\
3.927 \mathrm{E}-004 \\
3.83\end{array}$ & $\begin{array}{l}0.21 \\
1.309 \mathrm{E}-004\end{array}$ & $<0.0001 * *$ \\
\hline Ash Content & $\begin{array}{l}\text { Regression } \\
\text { Residual } \\
\text { Total }\end{array}$ & $\begin{array}{l}19 \\
2 \\
21\end{array}$ & $\begin{array}{l}0.92 \\
8.078 \mathrm{E}-007 \\
0.92\end{array}$ & $\begin{array}{l}0.048 \\
4.039 \mathrm{E}-007\end{array}$ & $<0.0001 * *$ \\
\hline Total Protein & $\begin{array}{l}\text { Regression } \\
\text { Residual } \\
\text { Total }\end{array}$ & $\begin{array}{l}20 \\
1 \\
21\end{array}$ & $\begin{array}{l}157.69 \\
1.510 \mathrm{E}-004 \\
157.69\end{array}$ & $\begin{array}{l}7.88 \\
1.510 \mathrm{E}-004\end{array}$ & $0.0034 * *$ \\
\hline Carbohydrate & $\begin{array}{l}\text { Regression } \\
\text { Residual } \\
\text { Total }\end{array}$ & $\begin{array}{l}20 \\
1 \\
21\end{array}$ & $\begin{array}{l}135.30 \\
7.408 \mathrm{E}-005 \\
135.30\end{array}$ & $\begin{array}{l}6.77 \\
7.408 \mathrm{E}-005\end{array}$ & $0.0026^{* *}$ \\
\hline
\end{tabular}

\section{References}

Ajita T., Jha S. K. (2017) Extrusion Cooking Technology: Principal Mechanism and Effect on Direct Expanded Snacks - An Overview. International Journal of Food Studies, 6 113-128.

Alam M. S., Kaur J., Khaira H., Gupta K. (2016) Extrusion and Extruded Products: Changes in Quality Attributes as Affected by Extrusion Process Parameters: A Review. Critical Reviews in Food Science and Nutrition, 56 (3) 445-473.

Alamu E. O., Maziya-Dixon B., Popoola I., Gondwe T., Chikoye D. (2016) Nutritional evaluation and consumer preference of legume fortified maizemeal porridge. Journal of Food and Nutrition Research, 4 (10) 664-670.

AOAC (2014) Official Methods of Analysis of AOAC International. (18th edition). Aithersburg, MD, USA.

Asare E. K., Sefa-Dedeh S., Afoakwa E. O., Sakyi-Dawson E., BuduA. S. (2010) Modeling the effects of feed moisture and ingredient variations on the physical properties and functional characteristics of extruded sorghum-groundnut-cowpea blends using response surface methodology. International Journal of Food Engineering, 6 (4) 1-17.

Ashworth A., Draper A. (1992) The potential of traditional technologies for increasing the energy density of weaning foods: A critical review of existing knowledge with particular reference to malting and fermentation. WHO/CBD EDP/92.4.

Awobusuyi T. D., Siwela M. (2019) Nutritional Properties and Consumer's Acceptance of Provitamin A-Biofortified Amahewu Combined with Bambara (Vigna Subterranea) Flour. Nutrients, 11 (7) 1476.

Bhattacharya M., Hanna, M.A. (1985) Extrusion processing of wet corn gluten meal. Journal of Food Science, 50 1508-1509.

Borah A., Mahanta C. L., Kalita D. (2015) Quality Attributes of Extruded Breakfast Cereal from Low Amylose Rice and Seeded Banana (Musa Balbisiana, ABB). Journal of Food Research and Technology 3 (1) 23-33.

Cocharan W. G., Cox G. M. (1957) Article title In: Experimental Designs. Bradley R.A. Kendall D.G., Hunter J.S., Watson G.S. (ed), $335-375$.

Ferrari A. C., Leonel M., Mischan M. M. (2014) Physical properties of snacks made from cassava leaf flour Propriedades físicas de snacks de farinha de folhas de mandioca. In: Semina: Ciências Agrárias, Londrina - volume 35 (1) 317-326.

Huang Y. L., Ma Y. S. (2016) The effect of extrusion processing on the physiochemical properties of extruded orange pomace. Food Chemistry, 192 $363-369$.

Kothakota A., Navdeep J., Thimmaiah B. (2013) A study on evaluation and characterization of extruded product by using various by-products. African Journal of Food Science, 7 (12) 485-497.

Leszek Moscicki (2011) Extrusion-Cooking Techniques Applications, Theory and Sustainability. WILEY-VCH Verlag and Co. KGaA, Weinheim, Germany. 
Navale S. A., Swami S. B., Thakor N. J. (2015) Extrusion Cooking Technology for Foods: A Review. Journal of Ready to Eat Food, 2 (3) 66-80.

Odour P. M., Struszczyk M. H., Peter M. G. (2008) Characterization of Chitosan from Blowfly Larvae and Some Crustacean Species from Kenyan Marine Waters Prepared under different Conditions. Discovery and Innovation 20 (2) 129-142.

Offiah V., Kontogiorgos V., Falade K. O. (2018) Extrusion Processing of Raw Food Materials and by-products: A Review. Critical Reviews in Food Science and Nutrition, 59 (18) 2979-2998.

Ogunmodimu O. O, Ijarotimi O. S. Fagbemi T. N. (2015) Evaluation of nutritional properties of high protein-fiber based snacks formulated from wheat, soybean concentrate and cassava fiber. Sky Journal of Food Science, 4 (3) 030-041.

Olitino H. M., Onimawo I. A., Egbekun M. K. (2007) Effect of germination on chemical compositions, biochemical constituents and antinutritional factors of soybean (Glycine max) seeds. Journal Science Food Agriculture, 73 1-9.

Omohimi C. I., Sobukola O. P., Sarafadeen K. O., Sanni L. O. (2013) Effect of Process Parameters on the Proximate Composition, Functional and Sensory Properties of mucuna bean flour. International Journal of Biological, Biomolecular, Agricultural, Food and Biotechnology Engineering, 7 (4) $269-278$.

Patil S., Brennan M., Mason S., Brennan C. (2016) The Effects of Fortification of Legumes and Extrusion on the Protein Digestibility of Wheat Based Snack. Foods, 5 (4) 26.

Reddy M. K., Kuna A., Lakshmi-Devi N., Krishnaiah N., Kaur C., Nagamalleswari Y. (2014) Development of extruded Ready-To-Eat (RTE) snacks using corn, black gram, roots and tuber flour blends. Journal of Food Science and Technology 51 (9) 1929-1937.

Rimm E. B., Ascherio A., Giovannucci E., Spiegelman D., Stampfer M. J., Willett W. C. (1996) Vegetable, fruit, and cereal fiber intake and risk of coronary heart disease among men. JAMA, $275447-451$.

Rizzo G., Baroni L. (2018) Soy, Soy Foods and Their Role in Vegetarian Diets. Nutrients, 10 (1) 43.

Samaila J., Nwabueze T. U. (2013) Quality Evaluation Of Extruded Full Fat Blend of African Breadfruit-Soybean-Corn Snack. International Journal of Scientific and Technology Research 2(9) 212-216.

Schulze M. B. (2004) Sugar-Sweetened Beverages, Weight Gain, and Incidence of Type 2 Diabetes in Young and Middle-Aged Women. JAMA, 292 (8) 927.

Singh D., Chauhan G. S., Suresh I., Tyagi S. M. (2000) Nutritional quality of extruded snakes developed from composite of rice broken and wheat bran. International Journal of Food Properties, 3 421- 431.

Singh S., Rainam C. S., Bawa A. S., Saxena D. C. (2003) Sweet potato-based pasta product: optimization of ingredient levels using response surface methodology. International Journal of Food Science and Technology, 38 1-10.

Singh S., Gamlath S., Wakeling L. (2007) Nutritional aspects of food extrusion: A review. International Journal of Food Science and Technology, 42 916-929.

Sobowale S. S., Adebo O. A., Adebiyi J. A. (2017) Development of a twin screw extruder. AgricEngInt: CIGR Journal Open access at http://www. cigrjournal.org, 19 (4) 181-186.

Wang W. M., Klopfenstein C. F. (1993) Effects of twin-screw extrusion on the nutritional quality of wheat, barley, oats. Cereal Chemistry, $70712-725$.

Wolf B. (2010) Polysaccharide functionality through extrusion processing. Current Opinion in Colloid and Interface Science, 15 50-54.

Yusuf M., Halilu M., Filli K. B. (2018) Influence of Extrusion Variables on Proximate Composition Some Nutrient and Antinutrient Contents of Dakuwa Extrudates Produced from Blends of Sorghum (Sorghum bicolour L) Groundnut (Arachis hypogea L) and Tigernut (Cyperus esculentus). Current Journal of Applied Science and Technology, 26(4) 1-20. 